DOI https://doi.org/10.18551/rjoas.2017-08.23

\title{
THE ROLE OF CORPORATE SOCIAL RESPONSIBILITY DISCLOSURE TOWARD COMPANY STOCK PRICE CRASH RISK
}

\author{
Handiyono Michella Yessica* \\ Postgraduate Program, Faculty of Economics and Business, University of Brawijaya, \\ Indonesia
}

Sukoharsono Eko Ganis, Saraswati Erwin

Faculty of Economics and Business, University of Brawijaya, Indonesia

*E-mail: michella.yessica@gmail.com

\begin{abstract}
This study aims to analyze the influence of corporate social responsibility disclosure to company stock price crash risk. If socially responsible companies are committed to high standards of information transparency and do not hide bad news, they will have a low risk of crash. However, if the manager reports CSR to distract the stakeholder from bad news, the CSR will be associated with a high risk of the company stock crash. The study was conducted at Indonesian manufacturing companies registered on the IDX (BEI) for the 2010-2015 period Hypothesis testing technique used a multiple regression analysis. The results showed that activities of the corporate social responsibility disclosure by the company did not have a significant relationship to the risk of the company stock price crash. This study also found that companies that conduct and report social responsibility activities simultaneously have a low risk of crashes on their company's stock price but cannot prove the relationship between the two. The implication is that social accountability reports in Indonesia are still limited to reports only and have not been considered as anything that can contribute to add value to the company or that may prevent the company from unethical behavior.
\end{abstract}

\section{KEY WORDS}

Social responsibility, crash risk, news, agency problem.

Trust from investors or potential investors will be very beneficial for a company. The more investors who believe in a company, the stronger the desire of investors to invest in the company will be. Stock prices are one of several indicators of the company success and good performance. If stock prices continue to rise, then investors will assume that the company is in good condition and holds a good performance as well (Zuliarni, 2013).

One of the factors that emerges as a prominent predictor of stock price crash risk is the tendency of management to withstand bad news from investors (Hutton et al., 2009; Kim et al., 2014). Kim et al. (2014) following Chen et al. (2001) defines the stock price crash risk as a conditional skewness of the stock return distribution. Such skewness can capture the asymmetry at risk, especially a downside risk. Knowing how much risk involved is important for investors to determine the investment measures.

Chen et al.(2001) expressed in his research that the overall return on the stock market has an asymmetric distribution. According to Chen, the biggest market movement is usually a decline occurs rather than an increase in stock prices and the stock market is likely to experience melt down. In his research Chen said that the return on the stock market reflects the existence of a negative skewness or the tendency of volatility to rise with a negative return.

Lack of information transparency will increase the risk of a future crash in the company's stock price by allowing managers to hide and accumulate bad news (Hutton et al., 2009; Kim and Zhang, 2010; Kim et al., 2011). If a manager within a company detains and accumulates 
bad news by not reporting company internal issues (such as delayed projects, decreased profits, CEO succession, etc.), then the stock price of the company will be overvalued. When accumulated, those bad news will finally reached a critical point, then all bad news will be suddenly released at once to the stock market. As a result simultaneously released bad news causes the stock price to crash (Kim et al., 2011). The manager's behavior is consistent with the agency theory. Manager's concerns about his career or incentives lead to the emergence of a variety of managerial misbehavior that is likely to harm the company (Kim et al., 2014). Kim et al .(2014) argued that manager misbehavior such as hiding bad news can be avoided if the company upholds high ethical standards.

Companies that have high ethical standards tend to have high social responsibility and tend to be more transparent in expressing financial statements (Sun et al., 2010; Dewi et al., 2014). Furthermore, several studies provide different views on the CSR implications on manager behavior like accumulating bad news and the transparency in the company's financial statements. Companies that are socially responsible tend to have a sense of responsibility in their behavior to report the company finance and show evidence of a lack of opportunistic behavior (Kim et al., 2012). The high corporate social responsibility shows the company's commitment to high ethical standards and has a positive impact on the quality of accounting information (Kim et al., 2014). Thus, the possibility of these companies are associated with the risk of stock price crash will be lower (Gelb and Strawser, 2001; Kim et al., 2014).

However, behind the positive popularity of CSR, Friedman (1970) expressed his concern that CSR is a form of agency problem within the company. Hemingway and Maclagan in Kim et al. (2014) also argue that one of the motivations for a company to adopt CSR is to cover managers misbehavior. The proof is that some researchers have found that CSR can be used to mask improper behaviors of the manager such as earning management practices (Sun et al., 2010; Scholtens and Kang, 2013). Furthermore, Kim et al. (2014) argues that managers have the possibility to use CSR as an investor distraction from bad news. Enron, for example, involved in massive accounting fraud and caused its collapse in 2001. Consistent with this view, some studies have found a positive relationship between CSR and earnings management (Petrovits, 2006; Prior et al, 2008).

In Indonesia, companies start implementing CSR since the issuance of Law no. 40 of 2007 concerning limited liability companies. The law explicitly requires companies engaged in business activities in the natural resource field to be obliged to carry out social and environmental responsibility (Art. 74 para. 1). In addition the company is also required to report on the implementation of social and environmental responsibility in the annual report (Art. 66 para. 2). The same applies to the Law No. 25 of 2007 concerning investment stating that every investor is obliged to carry out a corporate social responsibility (Art. $15 \mathrm{~b}$ ), and if there are violations the administrative and other sanctions will be imposed as provided in Article 34 (Dewi et al., 2014).With the obligation of CSR and various companies try to fulfill their corporate social responsibility, it becomes reasonable that in making investments, investors will consider companies that have good CSR performance as a candidate for investment place. This of course will make the implementation of CSR affects the stock of the company (Becchetti et al., 2012).

There are a variety of previous studies that review a CSR from all points of view such as improving the company financial performance (Roman et al., 1999; Jiao, 2010; Kim and Statman, 2012), lowering firm risk [1], As a shield of managers' unethical behavior such as earnings management (Petrovits, 2006; Prior et al, 2008; Sun et al., 2010; Bert and Kang, 2012), affect on stock prices and broad market movement (Becchetti et al., 2012; Kruger, 2015), etc. Similar research is also conducted in Indonesia (Hermawan, S., and Maf'ulah, A. N., 2014; Dewi et al., 2014).

A study of Kim et al. (2014) tries to take another point of view that highlights the disclosure of the corporate social responsibility focusing on each company (firm-specific). Kim found that corporate social responsibility has a mitigating effect on the stock price crash risk in 
the company but the role of the corporate social responsibility towards the occurrence of a stock price crash of a company is more visible when the company has ineffective corporate governance and low level of institutional ownership. Thus, the interesting phenomenon researched by Kim brings this research to replicate a research by Kim et al. (2014) that aims to analyze the role of corporate social responsibility disclosure to the risk of stock price crash in Indonesian manufacturing companies, particularly on 2010-2015 period.

\section{LITERATURE REVIEW}

Stakeholders Theory. Stakeholders are parties who have an interest in a company that can affect or can be influenced by the activities of said company (Zaenuddin, 2007). Freeman and McVea (2001) in their research argue that, the idea of a stakeholder approach shows that managers must formulate and implement a process that can meet and satisfy the needs of certain groups of interest in the business. The main task of this process is to manage and integrate the relationships and interests of shareholders, employees, consumers, suppliers, communities and other groups in a way that ensures long-term success of the company. The stakeholder approach emphasizes the active role of management in the company's business environment, its relationships, and promotes common interests (Freeman and McVea, 2001).

Robert (1992) in his research argues that the disclosure of corporate social responsibility is a means for companies to negotiate relationships between companies and their stakeholder. According to Jensen (2001), CSR is a way for managers of a company to satisfy their stakeholders. Robert (1992) states that the Stakeholder theory is the right foundation if used for empirical analysis of corporate social responsibility disclosure. Stakeholder theory forms the theoretical foundation for analyzing the impact of economic performance, strategic posture on social responsibility activities, and the intensity of stakeholder power at the level of corporate social responsibility disclosure.

Agency Theory. Jensen and Meckling (1976) and Ross (1973) define agency relationships as a contract in which one or more parties (principals) involve another party (agent) to do some things on behalf of the principal involving the delegation of some decision-making authority to the agent.

According to Roth and O'Donnell (1996) regarding the agency problem that occurred in the relationship between the principal and the agent is that the problem arises from a goal discrepancy between the principal and the agent (conflict of interest) and the principal difficulty in monitoring or verifying the agent's behavior. The non-conformance of the goal is based on the assumption that both the principal and the agent are utility maximizers. Thus, the agent will pursue his own interests, which may deviate from the principals' major interest.

Principals can limit the agency problems by conducting monitoring costs or by designing appropriate incentives for agents (Jensen dan Meckling, 1976; Roth and O'Donnell, 1996). In simple situations, principals can invest resources to directly monitor agency actions. However, in more complex situations, difficulty in monitoring or verifying the results of agent behavior will lead to information asymmetry. In reducing agent opportunistic actions, agency costs are required to take actions that minimize the occurrence of misbehavior by agents. There are three kinds of agency costs according to Jensen and Meckling (1976) include monitoring expenditures, bonding expenditure, and residual loss.

Corporate Social Responsibility and its Disclosure. A company is not only tied to the maximization of the shareholders wealth and assets. Companies must also care about the interests of employees and consumers, safeguarding the work opportunities of the less fortunate minorities, protecting the environment and ecology, etc. Carroll (1991) expressed his idea of a CSR image in a company in "the pyramid of corporate social responsibility".

In July 2007, Indonesia was the first country declaring the mandatory legislation on CSR, which applies to companies using natural resources. Stipulation of Law No. 40 Year 2007 in Indonesia does not appear to have a major effect on CSR activities and reporting on companies listed on the Indonesian stock exchange. Other law relating to CSR is Law No. 25 
of 2007 concerning investment, which in Article 15 (b) stipulates that every investor shall carry out the corporate social responsibility, and in Article 34 it regulates in detail the sanctions against businesses and individuals not performing CSR. However, in 2009 only 33 percent of the 392 large companies in Indonesia implemented the CSR (Dewi et al., 2014).

Company Stock Price Crash Risk. Harry Markowitz in his research regarding properties of distributive risk and return states that there are 4 moments in the return distribution. Those moments are mean, variance, directional skewness, and kurtosis (Mun, 2006). Kim et al. (2014) following Chen et al. (2001) in his research defines the crash risk in their research as a conditional skewness of the return distribution. Crash risk can capture the asymmetry at risk, especially the important downside risk for investment and risk management decisions. Conditional skewness is the third moment of the return distribution that can predict the accumulation of information hidden by market players that tend to occur when market conditions are declining by identifying whether a skewness is negative or positive.

The skewness provides information relating to the symmetry of a distribution If a skewness has a 0 value, then it indicates a symmetric return distribution. If a skewness is positive (right-skewed) that the investment made has a frequent low losses and some extreme gain. If the return distribution has a negative skewness (left-skewed) then the investment made has a frequent low gain and some extreme losses (Frömmel, 2013).

Using this understanding, Chen et al. (2001) and Kim et al. (2014) argues that the more negative the skewness curve the greater risk of stock price crash will be in a company. The company stock price crash risk is associated with the asymmetry of information that occurs between companies and investors. When a company's management engages in divergent behavior such as hiding bad news from investors, then sooner or later the cost to conceal bad news will become too big. Bad news that can no longer be detained and will simultaneously come out to the market and cause the stock price to fall immediately (crash). This is also called a bubble theory (Chen et al., 2001). If a skewness is negative, then the stock return distribution of the company has several possible high crash and vice versa (Kim et al., 2014).

The Effect of Social Responsibility Disclosure to Company Stock Price Crash Risk. Several studies have documented the distribution of stock returns showing large negative stock returns (or the occurrence of a crash) in stock prices have higher frequencies and more common in occurrence than large positive stock returns (Chen et al., 2001; Hong and Stein., 2003). In line with the research of Chen and Hong and Stein, several studies then tried to predict the cause of the crash on the stock price of a company. One of the biggest predictors found is the manager's tendency to conceal bad news from investors (Jin and Myers, 2006; Hutton et al., 2009).

Agency theory states that agency issues in a company arise because of a mismatch between the main objectives of the principal and the agent. According to agency theory, previous research mentions that managers hold bad news of the company from investors because they are concerned about career continuity and compensation (Ball 2009, Graham et al., 2005; Khan and Watts, 2009; Kothari et al., 2009). Bad news that are constantly collected and then accumulated and reach the point when bad news can be no longer detained, then all the bad news then released simultaneously and cause the stock price of a company to directly experience crashes (Chen et al., 2001; Hong and Stein., 2003). Hutton et al. (2009), Kim et al. (2011), and Kim and Zhang (2013) support the above view by providing that several factors such as unclear financial reporting, tax avoidance, and equity-based incentives for corporate executives can cause crashes.

In the stakeholder Theory it is mentioned that managers must formulate and implement a process that can meet and satisfy the needs of certain groups, in this regard is stakeholders. Robert (1992) in his research states that corporate social responsibility activities are one of manager activities to satisfy the company stakeholders and support the theory of stakeholders. However, previous research provides several different views related to the implication that the corporate social responsibility can prevent or minimize the behavior of managers who withstand bad news and transparency of financial statements. 
Some studies have found that socially responsible corporate also have a high responsibility for financial reporting and show low earnings management behavior, thereby it demonstrates that companies have a high ethical commitment and have a positive impact on the quality of accounting information (Kim et al., 2012; Sun et al., 2010). A study of Kim et al. (2014) also found that companies with high levels of social responsibility have low levels of bad news collection.

Similar to Kim, Gelb and Strawser (2001) found that companies carrying out social responsibility activities provide more financial disclosure. This is consistent with the idea that, the company sees the increase in such disclosure as a socially responsible form of behavior and included in the overall practices of the corporate social responsibility. Similarly, with a research conducted by Cho et al. (2013) which suggests that companies with a good quality of social accountability will minimize the occurrence of information asymmetry.

On the other hand, Jensen (2001) asserted that the stakeholder theory does not give managers a clear limit of the extent to which a manager can act to satisfy stakeholders. Similar concerns are also expressed by Friedman (1970) who argues that the corporate social responsibility can represent an agency problem that occurs within a company when used only to satisfy stakeholders. Hemingway and Maclagan (2004) and Bradley (2009) suggest that the company's motivation in adopting corporate social responsibility activities is to cover up corporate unethical behaviors. Kim et al. (2014) also noted that there are concerns that managers can use corporate social responsibility opportunistically to advance careers, retain compensation, and other personal agenda. This is supported by numerous studies that find a positive relationship between the corporate social responsibility and earnings management and tax avoidance (Hoi et al., 2013; Petrovist, 2006; Prior et al., 2008; Sun et al., 2010).

The relationship of the corporate social responsibility to the risk of a company's stock crash is then further investigated by Kim et al. (2014) who found that there was a mitigating effect of corporate social responsibility disclosure to the risk of the company's crash. Furthermore, Kim et al. (2014) found only a positive relationship between a disclosure of the corporate social responsibility to the risk of a company's stock crashes only when the company had weak corporate governance and low institutional ownership level.

Based on empirical theoretical and empirical studies of the relationship between the role of the social responsibility disclosure to the risk of previous company stock price crashes, it can be concluded that there are several different opinions and inconsistent research results. For that reason, the researcher wished to see the relation between the disclosure of the social responsibility of the company and the company stock price crash risk in Indonesia. Based on the rationale above, the theoretical review, and the results of previous research, the hypothesis of this study is the company social responsibility disclosure has an influence to the company stock price crash risk.

\section{METHODS OF RESEARCH}

Research Design and Sampling. This study uses companies in the manufacturing industry that go public as listed on the Indonesia Stock Exchange from 2010 to 2015 as a population. The sample of this research is chosen by using the purposive sampling method, that is a sample selection based on certain criteria. Sample selection criteria are as follows:

1. Manufacturing companies listed on the Indonesia Stock Exchange from 2010 to 2015.

2. Manufacturing companies that publish annual reports continuously from 2010 to 2015.

Based on established criteria, of the total population of 142 manufacturing companies listed on BEl in 2010 to 2015 , we obtained 61 companies with a total 233 research sample for 6 years. We used multiple regression analysis to test the hypothesis.

Operationalization and Measurement of Variables. As the independent variable, social responsibility disclosure are measured using the MSCI ESG index according to a study of Kim et al., (2014), which consists of two separate categories of strength and concern as listed in Table 1. 
Table 1 - MSCI ESG ratings

\begin{tabular}{|c|c|}
\hline STRENGTH+CONCERN & CONCERN \\
\hline Community & Alcohol \\
\hline Diversity & Gambling \\
\hline Employee Relation & Firearms \\
\hline Environment & Military \\
\hline Products & Nuclear Power \\
\hline
\end{tabular}

Source: KLD STATS and ESG Rating.

Such points are assessed from the sustainability report and annual report of the company, and also the CSR news. In case a company fails to release a sustainability report, then the data are taken from the annual report and CSR news. Each point is assigned by a value of 1 if the point is within the corporate social responsibility sequence, and is assigned a value of 0 if not present. According to a study of Kim et al. (2014), from the number of points in each category are then calculated under the total number (net count) of the disclosure of social responsibility that is:

NETcount: total strength - total concern

The net count results are then transformed according to the formula used in the research of Kim et al.(2014), to produce CSR scores with a range from 0 to 1.

$$
\text { CSR company i year } t=\frac{(\text { NETcount } x \text { firm CSRmin industry } \text { i year })}{(\text { firm CSRmax industry } i \text { year } \mathrm{t} x \text { firm CSRmin industry } i \text { year } t)}
$$

Company Stock Price Crash Risk (CRASH). Dependent variable in this research is the company stock price crash risk (CRASH). Company stock price crash risk as intended in this study its definition follows the research of Chen et al. (2001) and Kim et al. (2014) that is a conditional skewness in the distribution of return.

There are two models of company stock price crash risk calculation according to Chen et al. (2001) and Kim et al. (2014) that is NCSKEW and DUVOL model. NCSKEW is a crash risk calculation by calculating a negative conditional skewness of the weekly return of each company during a fiscal year. The higher the value of NCSKEW then indicates the greater crash risk.

$$
\operatorname{NCSKEW}_{j, t}=-\frac{\left[n(n-1)^{\frac{3}{2}} \Sigma W_{j, t}^{3}\right]}{(n-1)(n-2)\left(\Sigma W_{j, t}^{2}\right)^{3 / 2}}
$$

Where: $n$ is the total amount of weekly return in 1 year $t$ and $w$ is the weekly return firm $\mathrm{j}$ in year t.

DUVOL is used to calculate the down-to-up volatility for possible crashes. The weekly returns of each company are divided into two groups i.e.: up-week when returns are above the annual average and down-week when returns are below the annual average. DUVOL does not involve the third moment (skewness) so it is not affected by extreme weekly returns. The higher the DUVOL value indicates the greater crash risk (Chen et al., 2001; Kim et al., 2014).

$$
\text { DUVOL }_{\mathrm{j}, \mathrm{t}}=-\log \left\{\frac{\left(\mathrm{n}_{\mathrm{u}}-1\right) \sum_{\mathrm{Down}} \mathrm{W}_{\mathrm{j}, \mathrm{t}}^{2}}{\left(\mathrm{n}_{\mathrm{d}}-1\right) \sum \mathrm{Up}_{\mathrm{p}} \mathrm{W}_{\mathrm{j}, \mathrm{t}}^{2}}\right\}
$$


Where $n_{u}$ is the total up weeks in year $\mathrm{t}, n_{d}$ is the total down weeks in year $\mathrm{t}, W$ is the weekly return firm $\mathrm{j}$ in year $\mathrm{t}, \sum_{D o w n} W_{j, t}$ is the total weekly returns on down weeks of firm $\mathrm{j}$ on year $\mathrm{t}$, and $\sum_{U p} W_{j, t}$ is the total weekly returns on up weeks firm $\mathrm{j}$ on year $\mathrm{t}$.

Control Variable. This research uses several control variables following Chen et al. (2001) and Kim et al. (2014). Those variables are change in trading volume (CTV) which is a proxy from the intensity of opinion among investors (share turnover year $\mathrm{t}$ - share turnover year t-1), past return (PR), market-to-book ratio (MB), firm Size (FS), Stock Volatility (STVOL) which is stock price stability (standard deviation of weekly returns of firm $i$ in fiscal year $t$ ), Financial leverage (LEV), Profitability (ROA), and Earning Management (EM) using performance match discretionary accrual method by Kothari et al. (2005).

Data Collection Technique. Data collection techniques used in this study are archival and data sources are taken from the database (Jogiyanto, 2014). Data collection is taken from a third source and collected by copying the data of each sample company from information sources such as sustainability report, annual report, news, stock price on yahoo finance. In addition, library studies are also conducted from related sources such as books, journals, and articles related to this research.

Hypothesis Testing Technique. The method used in this research is a multiple regression analysis. The regression model used in this research is as follows:

$$
C R A S H=\beta_{0}+\beta_{1} C S R+\beta_{2} C T V+\beta_{3} P R+\beta_{4} M B+\beta_{5} F S+\beta_{6} S T V O L+\beta_{7} L E V+\beta_{8} R O A+\beta_{9} E M+\varepsilon_{i t}
$$

Where CRASH is the company stock price crash risk, $\beta_{0}$ is the constant, $\beta_{1 \ldots 9}$ are the regression coefficients, CSR is corporate social responsibility disclosure, CTV is change in trading volume, $\mathrm{PR}$ is past return, MB is the market to book ratio, FS is the firm size, STVOL is for stock volatility, LEV for financial leverage, ROA for profitability, EM for earning management, and $\varepsilon$ it for the error.

\section{RESULTS AND DISCUSSION}

Descriptive Statistic. In descriptive statistics table, the descriptive can be seen from NCSKEW average value obtained is equal to -0.6944884 . Minus value obtained in the average value of NCSKEW shows that the stock prices in firms under study have a small tendency to experience crashes that are affected by the third moment or where there is an extreme weekly return. While on DUVOL, it has an average value of -0.0668059 . The average value of DUVOL, which is also below zero, indicates that the manufacturing firms under study have a very small crash risk if unaffected by the extreme weekly returns on their stock prices. Lower DUVOL average value than NCSKEW indicates that when a company's stock is affected by extreme weekly returns, the risk of crashes will be greater.

Table 2 - Descriptive Statistic

\begin{tabular}{|c|c|c|c|c|c|}
\hline Variable & $\mathrm{N}$ & Minimum & Maximum & Mean & Std. Deviation \\
\hline NCSKEW & 223 & -3.90021 & 2.60401 & -.6944884 & 1.15445407 \\
\hline DUVOL & 223 & -.59247 & .44584 & -.0668059 & .17584565 \\
\hline CSR & 223 & -.04348 & 1.00000 & .5752454 & .26644590 \\
\hline CTV & 223 & -2.96 & .06 & -1.0820 & .77850 \\
\hline PR & 223 & -.02043 & .02206 & .0021137 & .00761053 \\
\hline MB & 223 & .0135 & 1.8674 & 1.011721 & .4371381 \\
\hline FS & 223 & .03147 & .03810 & .0349140 & .00174416 \\
\hline STVOL & 223 & .00000 & .11566 & .0550970 & .02056936 \\
\hline LEV & 223 & .03312 & 1.03249 & .4937512 & .20696068 \\
\hline ROA & 223 & -.0015 & .0852 & .048795 & .0190022 \\
\hline EM & 223 & .04 & .30 & .2090 & .04460 \\
\hline
\end{tabular}

Source: Statistic Calculation. 
CSR variable reflecting the social responsibility of the firm, from the average value that the variables obtained can be seen that the company in this study has a social responsibility value that ranges around 0.5752454 or about $57.5 \%$ on average, not high and not too low. This result indicates that those companies have not carried out social responsibility in their maximum capacity and need further development.

CTV is a change in trading volume as a proxy of the intensity of disagreements among investors, with a mean value of CTV on -1.0820 , which is below zero indicating a low change in annual trade volumes on average. Based on these results, the intensity of disagreements among investors over the company's stocks is quite low and affecting the volatility and liquidity of stock prices in the market. Past return of the company is described by the PR variable. Based on the average value of the PR variable indicates that the average stock return earned by the company is quite low by only $0.2 \%$ on average per period.

Furthermore, there are $\mathrm{MB}$ variables that describe the market-to-book ratio. The Average value of MB (1.011721) indicates that some firms have high market-to-book ratio which can indicate that the average of the companies has a high range of stock price. High stock prices on a company can indicate that investors are optimistic about the company's growth. The firm size is represented by the FS variable. From the data, if the minimum value $(0.03147)$ describes the small company and the maximum value $(0.03810)$ describes the large company, it can be seen that most of the companies included in this research sample tend to be medium size company (mean $=0.0349140$ ).

Stock volatility is represented by the STVOL variable. Based on the minimum and maximum value of STVOL, the standard of stock volatility of the studied company has a range between $0 \%$ to $11.566 \%$ with an average value of $5.50970 \%$, it can be concluded that the average firms studied to have low stock volatility level. The company leverage is represented by LEV variable. Based on the obtained average value it shows that most companies still have a balanced comparison between the total composition of debt and capital.

Meanwhile, for ROA Variable that reflects profitability, the average value of 0.048795 means that the company is able to generate the net profit up to $4.9 \%$ of total company asset employed. In addition, based on minimum and maximum values, the smallest value of ROA that can be generated is $-1.5 \%$ and the largest is $8.5 \%$. Finally, it is the profit management variable represented by EM. Based on the average discretionary accrual value obtained (0.2090) which is closer to the maximum rather than the minimum, it shows that the manufacturing company in Indonesia on 2010 until 2015 take earnings management action with profit maximization pattern.

\section{RESULTS OF STUDY}

Based on the results of hypothesis testing it can be seen that the corporate social responsibility has no significant relationship to the company stock price crash risk. Thus it can be concluded that the results of this study receives a $\mathrm{H} 0$ that there is no influence between the disclosure of the corporate social responsibility and the company stock price crash risk and rejects a that there is an influence between CSR and the Crash risk in the company.

In addition there are 8 control variables in this research included past returns, market-to-book ratio, firm size, profitability, earning management, change in trading volume, stock volatility, and financial leverage. Of the eight variables, there are 4 variables that significantly affect in the role of the corporate social responsibility to the risk of the corporate stock crash include past returns stock volatility, change in trading volume, and profitability.

Based on the results of this study, it was found that activities of the corporate social responsibility disclosure have no influence towards the company stock price crash. The results of this study are not in line with a research conducted by Kim et al.(2014) who find the mitigating effect between CSR and the company stock price crash risk. The results of this study indicate that the high or low CSR reporting scores of a company does not affect the size of the risk of stock price crash at the companies. The results of this study indicate that 
managers do not use the performance of the corporate social responsibility to distract stakeholders from existing bad news. This does not mean the company has no agency problems, or the managers do not conceal bad news from stakeholders.

Table 3 - Summary of Multiple Regression Test Results

\begin{tabular}{|c|c|c|c|c|c|c|c|}
\hline \multicolumn{5}{|c|}{ NCSKEW } & \multicolumn{4}{c|}{ DUVOL } \\
\hline Variable & B & T-count & Sig & Variable & B & T- count & Sig \\
\hline Constant & -2.974 & -1.849 & .066 & Constant & -.249 & -.870 & .385 \\
\hline CSR & -.206 & -.833 & .406 & CSR & -.011 & -.258 & .797 \\
\hline PR & -92.843 & -9.513 & ${ }^{* * *} .000$ & PR & -9.598 & -5.533 & ${ }^{* * *} .000$ \\
\hline MB & .172 & .901 & .369 & MB & .042 & 1.247 & .214 \\
\hline FS & 64.085 & 1.407 & .161 & FS & 7.125 & .880 & .380 \\
\hline STVOL & -8.941 & -2.728 & ${ }^{* *} .007$ & STVOL & -.986 & -1.693 & ${ }^{*} .092$ \\
\hline LEV & .284 & .857 & .393 & LEV & -.023 & -.393 & .695 \\
\hline EM & .244 & .141 & .888 & EM & -.030 & -.098 & .922 \\
\hline ROA & 8.991 & 1.907 & ${ }^{*} .058$ & ROA & .406 & .485 & .628 \\
\hline CTV & -.042 & -.478 & .633 & CTV & .028 & 1.822 & ${ }^{*} .070$ \\
\hline${ }^{*}$ Statistical significance $10 \%{ }^{* *}$ Statistical significance $5 \%{ }^{* * *}$ Statistical significance 1\% \\
$\mathrm{R}^{2}$ NCSKEW $=0.412 \mathrm{R}^{2} \mathrm{DUVOL}=0.199$ \\
\hline
\end{tabular}

Source: Statistic Calculation.

As some studies have found that the activity and performance of a company's social responsibilities have an effect on stock prices and their market performance (Becchetti et al., 2012; Hill et al., 2007), but the results of this study find the performance of a company's social responsibility cannot fully illustrate the condition of the company, so that investors cannot use the performance of a company's social responsibility to assess future company prospects. There is no evidence in this study on the relationship between corporate responsibility disclosure and the risk of crashes in company stock prices, but based on table 2, the descriptive shows that company who implementing CSR have a low stock price crash risk simultaneously. Those result shows that the social responsibility disclosure here simply indicates that the company has carried out their accountability obligation to the environment and social community, but does not describe the company's internal conditions.

If further reviewed with the conditions in Indonesia and associated with the implementation of CSR in Indonesia, it may refer to the laws governing the CSR disclosure. As stated in Law no. 40 of 2007 concerning limited liability companies requiring a company carrying on its business in natural resources must exercise the social and environmental responsibility (Art. 74 para. 1) and companies shall report on the implementation of social and environmental responsibility (Art. 66 para. 2), the results of this study prove that the implementation of social and environmental responsibility in Indonesia is only limited to the report mandated and required by law.

New companies use CSR reports as a complement to their annual reports but the CSR itself has not coexisted with the company's vision and mission. The results of this study also show that, investors have not been able to consider CSR reports into their analysis. This is because the role of the corporate social responsibility disclosure in Indonesia has not been maximized. Furthermore, the results show that the most significant value in influencing the risk of the stock price crash are companies with high past return, stock volatility, Profitability, and the high volume of changes in trading.

\section{CONCLUSION AND SUGGESTIONS}

This study aims to analyze the relationship between a disclosure of the corporate social responsibility and the company stock price crash risk or the risk of stock price crash. This study also includes supporting factors that could affect the company's stock price crash risk. 
Supporting factors under control include past returns, market-to-book ratio, firm size, profitability, earning management, change in trading volume, stock volatility, and financial leverage.

The study was conducted at manufacturing companies registered on the IDX (BEI) for the 2010-2015 period This study uses 61 companies with a total of 233 samples. The study found that average manufacturing firms in Indonesia have small corporate stock price crash risk levels, especially when not affected by extreme weekly returns. This study also found that companies that conduct and report social responsibility activities simultaneously have a low risk of crashes on their company's stock price but cannot prove the relationship between the two.

This study proves that a disclosure of the corporate social responsibility has no role in increasing (or decreasing) the risk of crash on a company's stock price. The implication is that social accountability reports in Indonesia are still limited to reports only which is due to the obligation to carry out the activities of social responsibility by law. This reports cannot be used by investors to predict the internal condition of a company as of yet. This is becase social responsibility has not become an integral part with the corporate vision or mission.

In addition, the results of this study found that past returns, stock volatility, profitability and change in trading volume on a firm can affect the crash risk of company stock price. This study found that the higher the past return and stock volatility the lower the crash risk of corporate stock price become. Meanwhile, the higher level of profitability and change in trading volume of a company, the higher the risk of crash on company stock price. This study found no relationship between market-to-book-ratio, firm size, earnings management, and leverage against the risk of crashes on the company's stock price.

This research has not explored the aspect of good corporate governance in the corporate social responsibility disclosure. We take out good corporate governance aspect of the $\mathrm{MSCl}$ ESG index used to assess CSR because it differs from the social and environmental dimensions represented by other categories. So it is suggested to add this element to the next research in order to carry out a comparative influence of CSR without GCG and CSR with GCG aspect to the company stock price crash risk.

This research does not include the human rights aspects in CSR assessment because the research instrument of those aspects is not suitable with the situation in Indonesia. The items in the CSR assessment index may be modified to better align with the environment in Indonesia. The next researcher may also consider survey methods to assess CSR by using the same index. Further research can be conducted on industries other than manufacturing to see the effect of CSR disclosure on stock price crash risk on another industry

\section{REFERENCES}

1. Albuquerque, R. A., Durnev, A., dan Koskinen, Y. (2014). Corporate social responsibility and firm risk: Theory and empirical evidence. ECGI-Finance Working Paper, (359).

2. Ball, R. (2009). Market and political/regulatory perspectives on the recent accounting scandals. Journal of Accounting Research, 47(2), 277-323.

3. Becchetti, L., Ciciretti, R., Hasan, I., dan Kobeissi, N. (2012). Corporate social responsibility and shareholder's value. Journal of Business Research, 65(11), 1628-1635.

4. Bradley Jr, R. L. (2009). Corporate social responsibility and energy. Culture and civilization, 1, 181-197.

5. Brammer, S., Brooks, C., dan Pavelin, S. (2006). Corporate social performance and stock returns: UK evidence from disaggregate measures. Financial management, 35(3), 97-116.

6. Carroll, A. B. (1991). The pyramid of corporate social responsibility: Toward the moral management of organizational stakeholders. Business horizons, 34(4), 39-48. 
7. Chen, J., Hong, H., dan Stein, J. C. (2001). Forecasting crashes: Trading volume, past returns, and conditional skewness in stock prices. Journal of financial Economics, 61(3), 345-381.

8. Cho, S. Y., Lee, C., dan Pfeiffer, R. J. (2013). Corporate social responsibility performance and information asymmetry. Journal of Accounting and Public Policy, 32(1), 71-83.

9. Dewi, D. M., Sudarma, M., Djumahir; Sukoharsono, E. G. (2014) .CSR Effect on Market and Financial Performance. International Journal of Business and Management Invention.3(1).56-66,

10. Du, S., Bhattacharya, C. B., dan Sen, S. (2010). Maximizing business returns to corporate social responsibility (CSR): The role of CSR communication. International Journal of Management Reviews, 12(1), 8-19.

11. El Ghoul, S., Guedhami, O., Kwok, C.C., dan Mishra, D. R. (2011). Does corporate social responsibility affect the cost of capital?. Journal of Banking dan Finance, 35(9), 2388-2406.

12. Freeman, R. E., dan McVea, J. (2001). A stakeholder approach to strategic management.)

13. Friedman, M. (1970). The social responsibility of business is to increase its profits. New York, 122-124.

14. Frömmel, M. (2013). Portfolios and investments. BoD-Books on Demand.

15. Gelb, D. S., dan Strawser, J. A. (2001). Corporate social responsibility and financial disclosures: An alternative explanation for increased disclosure.Journal of Business Ethics, 33(1), 1-13.

16. Graham, J. R., Harvey, C. R., dan Rajgopal, S. (2005). The economic implications of corporate financial reporting. Journal of accounting and economics, 40(1), 3-73.

17. Harvey, C. R., dan Siddique, A. (2000). Conditional skewness in asset pricing tests. The Journal of Finance, 55(3), 1263-1295.

18. Hemingway, C. A., dan Maclagan, P. W. (2004). Managers' personal values as drivers of corporate social responsibility. Journal of Business Ethics, 50(1), 33-44.

19. Hermawan, S., dan Maf'ulah, A. N. (2014). Pengaruh Kinerja Keuangan Terhadap Nilai Perusahaan Dengan Pengungkapan Corporate Social Responsibility Sebagai Variabel Pemoderasi. Jurnal Dinamika Akuntansi,6(2).

20. Hill, R. P., Ainscough, T., Shank, T., dan Manullang, D. (2007). Corporate social responsibility and socially responsible investing: A global perspective. Journal of Business Ethics, 70(2), 165-174.

21. Hong, H., dan Stein, J. C. (2003). Differences of opinion, short-sales constraints, and market crashes. Review of financial studies, 16(2), 487-525.

22. Hutton, A. P., Marcus, A. J., dan Tehranian, H. (2009). Opaque financial reports, R 2, and crash risk. Journal of financial Economics, 94(1), 67-86.

23. Jensen, M. C., dan Meckling, W. H. (1976). Theory of the firm: Managerial behavior, agency costs and ownership structure. Journal of financial economics, 3(4), 305-360.

24. Jensen, M. C. (2001). Value maximization, stakeholder theory, and the corporate objective function. Journal of applied corporate finance, 14(3), 8-21.

25. Jin, L., dan Myers, S. C. (2006). R 2 around the world: New theory and new tests. Journal of financial Economics, 79(2), 257-292.

26. Jiao, Y. (2010). Stakeholder welfare and firm value. Journal of Banking dan Finance, 34(10), 2549-2561.

27. Jogiyanto, Hartono. (2014). Metodologi Penelitian Bisnis. Edisi 4. BPFE-Jogjakarta

28. Khan, M., dan Watts, R. L. (2009). Estimation and empirical properties of a firm-year measure of accounting conservatism. Journal of accounting and Economics, 48(2), 132-150.

29. Kim, J. B., Li, Y., dan Zhang, L. (2011). Corporate tax avoidance and stock price crash risk: Firm-level analysis. Journal of Financial Economics, 100(3), 639-662.

30. Kim, Y., Li, H., dan Li, S. (2014). Corporate social responsibility and stock price crash risk. Journal of Banking dan Finance, 43, 1-13. 
31. Kim, Y., dan Statman, M. (2012). Do corporations invest enough in environmental responsibility?. Journal of Business Ethics, 105(1), 115-129.

32. Kim, J. B., dan Zhang, L. (2013). Accounting conservatism and stock price crash risk: Firm-level evidence. Contemporary Accounting Research, Forthcoming.

33. Kothari, S. P., Leone, A. J., \& Wasley, C. E. (2005). Performance matched discretionary accrual measures. Journal of accounting and economics, 39(1), 163-197.

34. Kothari, S. P., Shu, S., dan Wysocki, P. D. (2009). Do managers withhold bad news?. Journal of Accounting Research, 47(1), 241-276.

35. Krüger, P. (2015). Corporate goodness and shareholder wealth. Journal of financial economics, 115(2), 304-329.

36. Mun, J. (2006). Modeling risk: Applying Monte Carlo simulation, real options analysis, forecasting, and optimization techniques (Vol. 347). John Wiley dan Sons.

37. Petrovits, C. M. (2006). Corporate-sponsored foundations and earnings management. Journal of Accounting and Economics, 41(3), 335-362.

38. Prior, D., Surroca, J., dan Tribó, J. A. (2008). Are socially responsible managers really ethical? Exploring the relationship between earnings management and corporate social responsibility. Corporate Governance: An International Review, 16(3), 160-177.

39. Roberts, R. W. (1992). Determinants of corporate social responsibility disclosure: An application of stakeholder theory. Accounting, Organizations and Society, 17(6), 595-612

40. Roman, R. M., Hayibor, S., dan Agle, B. R. (1999). The relationship between social and financial performance repainting a portrait. Business dan Society,38(1), 109-125.

41. Ross, S. A. (1973). The economic theory of agency: The principal's problem. The American Economic Review, 63(2), 134-139.

42. Roth, K., dan O'Donnell, S. (1996). Foreign subsidiary compensation strategy: An agency theory perspective. Academy of management Journal, 39(3), 678-703.

43. Scholtens, B., dan Kang, F. C. (2013). Corporate social responsibility and earnings management: Evidence from Asian economies. Corporate Social Responsibility and Environmental Management, 20(2), 95-112.

44. Sun, N., Salama, A., Hussainey, K., dan Habbash, M. (2010). Corporate environmental disclosure, corporate governance and earnings management.Managerial Auditing Journal, 25(7), 679-700.

45. Zaenuddin, A. (2007). Faktor-Faktor Yang Berpengaruh Terhadap Praktek Pengungkapan Sosial Dan Lingkungan Pada Perusahaan Manufaktur Go Publik (Doctoral dissertation, program Pascasarjana Universitas Diponegoro).

46. Zuliarni, S. (2013). Pengaruh Kinerja Keuangan Terhadap Harga Saham Pada Perusahaan Mining And Mining Service Di Bursa Efek Indonesia (BEI).Jurnal Aplikasi Bisnis, 3(1)a. 